Situs Jurnal : $\underline{\text { http://ejournal.stiepancasetia.ac.id/index.php/jieb }}$

Jilid 5 Nomor 2 Juli 2019

Hal $269-281$

\title{
ANALISIS HUBUNGAN STRES KERJA DENGAN PRESTASI KERJA KARYAWAN PADA PT. CJ CHEILJEDANG FEED KALIMANTAN
}

\section{Arief Noviarakhman Zagladi* dan Nurmalisa}

Abstract: This study aims to determine the level and relationship between work stress variable with employee performance at PT. CJ CheilJedang Feed Kalimantan. Sampling using nonprobability sampling technique is by incidental sampling type which means that sampling does not give equal opportunity or opportunity for every member of the population to be selected as sample and sample determination based on chance to meet the researcher with the respondent. And to determine the number of samples using a Slovin formula so as to obtain a minimum number of 90 (ninety) respondents out of 116 (one hundred and sixteen) populations assisted with SPSS computer application program to obtain relevant analysis results. The results of the research analysis showed that the level of job stress on employee performance is low but not very low. And the relation between work stress and employee performance got insignificant result because correlation analysis more than 0,05 .

Keywords: work Stress, Job Performance, correlation

Abstrak: Penelitian ini bertujuan untuk mengetahui tingkat dan hubungan antara variabel stres kerja dengan prestasi kerja karyawan pada PT. CJ CheilJedang Feed Kalimantan. Pengambilan sampel menggunakan teknik nonprobability sampling yaitu dengan jenis incidental sampling yang artinya pengambilan sampel yang tidak memberi peluang atau kesempatan sama bagi setiap anggota populasi untuk dipilih menjadi sampel dan penentuan sampel berdasarkan kebetulan bertemu peneliti dengan responden. Dan untuk menentukan jumlah sampel menggunakan rumus dari Slovin sehingga mendapatkan jumlah minimum 90 (sembilan puluh) responden dari 116 (seratus enam belas) populasi dibantu dengan program aplikasi komputer SPSS untuk mendapatkan hasil analisis yang relevan. Hasil analisis penelitian menunjukkan bahwa tingkat stres kerja terhadap prestasi kerja karyawan tergolong rendah namun tidak sangat rendah. Dan hubungan antara stres kerja dengan prestasi kerja karyawan mendapatkan hasil yang tidak signifikan karena hasil analisis korelasinya lebih dari 0,05.

Kata kunci : : Stres Kerja, Prestasi Kerja, hubungan

\section{Latar Belakang}

Perkembangan zaman dan globalisasi menuntut sebuah perusahaan untuk selalu melakukan perubahan-perubahan dalam ide dan inovasi yang memiliki daya saing. Merubah strategi berarti perusahaan juga harus mendesain ulang struktur dan sistem-sistem yang terkait didalamnya. Dampak dari kegiatan tersebut dirasakan langsung oleh karyawan sebagai motor penggerak pencapaian tujuan perusahaan. Adanya keterbatasan sumber daya dan jenis kepribadian dari karyawan menentukan sejauh mana karyawan dapat menyesuaikan diri terhadap perubahan ataupun melakukan penolakan yang berakibat timbulnya stres dalam bekerja. 
Stres itu sendiri dibedakan menjadi dua macam menurut Quick dan Quick (dalam Waluyo, 2014:92) yaitu stres positif (Eustress) yang artinya stres ini membuat seseorang menjadi bersemangat dan pekerjaannya menjadi lebih maksimal. Sedangkan stres negatif (Distress) adalah stres yang membuat seseorang menjadi frustasi, down dan tidak bersemangat. Bahaya stres diakibatkan karena kondisi kelelahan fisik, emosional dan mental yang disebabkan oleh adanya keterlibatan dalam waktu yang lama dengan situasi yang menuntut secara emosional.

Kalau stres itu dibiarkan maka akan berdampak juga pada prestasi kerja karyawan, sehingga harus diperhatikan penyebab dan mencari alternatif pemecahan masalah tersebut. Dengan itu perusahaan harus memiliki sumber daya manusia (SDM) yang bekerja dengan baik dan dilandasi oleh prestasi kerja yang tinggi. Karena memiliki prestasi kerja yang tinggi akan memberikan hasil yang baik juga untuk perusahaan.

Prestasi kerja seseorang ditunjukkan dengan keseriusannya dalam menyelesaikan tugastugas yang dibebankan kepadanya berdasarkan atas kecakapan, pengalaman, kesungguhan serta waktu. Prestasi kerja karyawan sangat berpengaruh terhadap kemajuan dan keberhasilan suatu perusahaan dalam mencapai suatu target atau tujuan. Untuk itu seorang atasan perlu mempunyai ukuran prestasi kerja para karyawan supaya tidak timbul suatu masalah. Informasi tentang prestasi kerja karyawan juga diperlukan pula bila suatu saat atasan ingin mengubah sistem yang ada.

Hubungan antara stres kerja karyawan dengan prestasi kerja karyawan ini jika karyawan mengalami stres dalam bekerja maka akan mempengaruhi prestasi kerja karyawan. Karena dengan mengalami stres kerja, secara tidak langsung pasti akan mempengaruhi pada prestasi kerjanya, misalnya seorang karyawan biasa menyelesaikan tugas-tugas yang diberikan dengan tepat waktu namun dengan mengalami stres pada pekerjaan akhirnya karyawan itu sendiri tidak dapat menyelesaikan dengan maksimal dan tepat waktu.

Penelitian ini dilaksanakan di PT. CJ CheilJedang Feed Kalimantan, yaitu salah satu perusahaan pakan ternak di Indonesia. Perusahaan melakukan kegiatan pemeliharaan ternak,memproduksi berbagai macam pakan unggas, seperti ayam petelur, ayam pedaging, puyuh dan lainnya. PT. CJ CheilJedang Feed Kalimantan terus mengembangkan rencana bagi keberlangsungan usaha di masa depan. PT. CJ CheilJedang Feed Kalimantan dituntut untuk memberdayakan sumberdaya perusahaan secara maksimal dan melakukan peningkatan baik kualitas produk ataupun sumberdaya manusia yang ada didalamnya, sehingga dapat meningkatkan prestasi karyawan serta mampu bersaing dalam memenuhi kebutuhan domestik maupun ekspor.

Stres yang pernah terjadi pada perusahaan PT. CJ CheilJedang Feed Kalimantan pada bagian office dimana karyawan dituntut oleh perusahaan ataupun pimpinan agar cepat menyelesaikan pekerjaannya dengan waktu yang sudah ditetapkan namun dengan banyaknya pekerjaan karyawan seringkali terdesak dalam menyelesaikan pekerjaannya. Sehingga membuat karyawan tertekan dengan keadaan yang memaksa untuk bekerja lebih cepat dan akhirnya terkadang membuat hasil pekerjaan karyawan tidak maksimal.

Salah satu data laporan yang mengindikasikan karyawan pada PT. CJ CheilJedang Feed Kalimantan mengalami stres dalam bekerja ditunjukkan pada Tabel 1. Dari data laporan presentase penyelesaian pekerjaan dikatakan sempurna jika presentase yang dicapai $100 \%$. Namun nyatanya realisasi berdasarkan data manajemen belum mencapai $100 \%$. Jadi bisa dikatakan prestasi berdasarkan dari data laporan presentase penyelesaian pekerjaan dalam kurun waktu 5 bulan terakhir tidak mencapai $100 \%$ dan akhirnya membuat karyawan mengalami stres dikarenakan tidak sempurnanya dalam penyelesaian laporan pekerjaan untuk setiap bulannya. 
Stres yang dialami karyawan pada PT. CJ CheilJedang Feed Kalimantan ini selain berdasarkan penyelesaian laporan yang dikerjakan tidak selesai dengan tepat waktu dan sempurna, ada stres lain yang berdasarkan dari data laporan target dan pencapaiannya dalam setiap bulan.

Tabel 1. Data Laporan Presentase Penyelesaian Pekerjaan Tahun 2017

\begin{tabular}{cclc}
\hline No & Bulan & \multicolumn{1}{c}{ Laporan } & Presentase Penyelesaian \\
\hline 1 & Juni & $\begin{array}{l}\text { Laporan harus selesai pada setiap } \\
\text { akhir bulan tanggal 30 }\end{array}$ & $80 \%$ \\
\hline 2 & Juli & $\begin{array}{l}\text { Laporan harus selesai pada setiap } \\
\text { akhir bulan tanggal 29 }\end{array}$ & $70 \%$ \\
\hline 3 & Agustus & $\begin{array}{l}\text { Laporan harus selesai pada setiap } \\
\text { akhir bulan tanggal 31 }\end{array}$ & $80 \%$ \\
\hline 4 & September & $\begin{array}{l}\text { Laporan harus selesai pada setiap } \\
\text { akhir bulan tanggal 30 }\end{array}$ & $80 \%$ \\
\hline 5 & Oktober & $\begin{array}{l}\text { Laporan harus selesai pada setiap } \\
\text { akhir bulan tanggal 31 }\end{array}$ & \\
\hline
\end{tabular}

Data target dan pencapaian dalam memasarkan produk PT. CJ CheilJedang Feed Kalimantan dalam waktu 5 bulan terakhir ditunjukkan pada Tabel 2.

Tabel 2. Data Laporan Target dan Pencapaian Perbulan Tahun 2017

\begin{tabular}{cccc}
\hline No & Bulan & Terget & Pencapaian \\
\hline 1 & Juni & $9.500 \mathrm{mt}$ & $8.975 \mathrm{mt}$ \\
\hline 2 & Juli & $11.500 \mathrm{mt}$ & $10.180 \mathrm{mt}$ \\
\hline 3 & Agustus & $12.000 \mathrm{mt}$ & $11.585 \mathrm{mt}$ \\
\hline 4 & September & $11.500 \mathrm{mt}$ & $10.723 \mathrm{mt}$ \\
\hline 5 & Oktober & $11.000 \mathrm{mt}$ & $10.435 \mathrm{mt}$ \\
\hline
\end{tabular}

Jadi dengan pencapaian target selama kurun waktu 5 bulan terakhir mengalami fluktuasi, namun dapat dilihat pada tabel diatas bahwa dalam 3 bulan terakhir mengalami penurunan dalam pencapaian target. Dan dapat dikatakan 3 bulan terakhir karyawan pada PT. CJ CheilJedang Feed Kalimantan ini sangat dituntut untuk dapat merubah angka pencapaian dari target yang sudah ditetapkan oleh perusahaan untuk bulan berikutnya. Dan dengan tuntutan yang melebihi dari biasanya maka inilah salah satu penyebab dari stres kerja yang akhirnya membuat prestasi dari seorang karyawan menurun.

Namun, dalam usaha perusahaan meningkatkan prestasi karyawan, tentu banyak masalah-masalah yang dihadapi karyawan seperti masalah budaya senioritas yang mungkin ada dalam perusahaan, pengaruh budaya terhadap sifat karyawan karena sebagian berasal dari Kalimantan Selatan, serta lingkungan dan iklim daerah Kalimantan Selatan tergolong panas yang akan menyebabkan suasana kerja menjadi kurang nyaman dan tidak menutup kemungkinan para karyawan akan terkena gejala stres. Pada akhirnya, dapat terjadi berbagai macam ketegangan dan kekhawatiran yang mengakibatkan para karyawan diperusahaan tersebut mengalami stres yang berkepanjangan.

Stres kerja merupakan salah satu penghambat dalam pemenuhan prestasi yang tinggi. Dan prestasi bisa didapat apabila karyawan dapat meminimalisir stres yang dialami. Berdasarkan 
latar belakang diatas maka penulis perlu mengangkat masalah tentang hubungan Stres Kerja Dengan Prestasi Kerja Karyawan pada PT. CJ CheilJedang Feed Kalimantan.

\section{Kajian Literatur}

Perilaku organisasi pada hakikatnya mendasar pada ilmu perilaku itu sendiri yang dikembangkan dengan pusat perhatiannya pada tingkah laku manusia dalam suatu organisasi. Bidang pengetahuan perilaku organisasi yang sudah di kembangkangkan sejak lama, nampaknya akhir-akhir ini mulai dirasakan kepentingannya. Perilaku organisasi merupakan bidang ilmu terapan yang dibentuk berdasarkan kontribusi dari sejumlah bidang yang berkaitan dengan perilaku.

pengertian perilaku organisasi yang lain dikemukakan oleh Kelly (dalam Thoha, 2014:9) ialah perilaku organisasi merupakan sebagai suatu sistem studi dari sifat organisasi seperti misalnya bagaimana organisasi dimulai, tumbuh dan berkembang dan bagaimana pengaruh terhadap anggota-anggota sebagai individu, kelompok-kelompok pemilih organisasi-organisasi lainnya dan institusi-institusi yang lebih besar.

Selanjutnya Thoha (2014:5) mengemukakan pendapat mengenai perilaku organisasi adalah "Suatu studi yang menyangkut aspek-aspek tingkah laku manusia dalam suatu organisasi atau suatu kelompok tertentu".

Menurut Gibson Ivancevich (dalam Hermita, 2011:17) "Stres sebagai suatu tanggapan adaktif, ditengahi oleh perdebatan individual dan / atau proses prikologis, yaitu suatu konsekuensi dari setiap kegiatan (lingkungan), situasi, atau kejadian eksternal yang membebani tuntutan psikologis atau fisik yang berlebihan terhadap seseorang".

Menurut Sunyoto (2014:216) Stres adalah konsekuensi setiap tindakan dan situasi lingkungan yang menimbulkan tuntutan psikologis dan fisik yang berlebihan pada seseorang.

Dari beberapa uraian diatas, penulis menyimpulkan bahwa stres merupakan suatu kondisi ketegangan yang mempengaruhi emosi, proses berfikir dan kondisi seseorang dimana ia terpaksa memberikan tanggapan melebihi kemampuan penyesuaian dirinya terhadap suatu tuntutan eksternal (lingkungan). Stres yang terlalu besar dapat mengancam kemampuan seseorang untuk menghadapi lingkungannya. Sebagai hasilnya, pada diri para karyawan berkembang berbagai macam gejala stres yang dapat mengganggu pelaksanaan kerja mereka.

Istilah prestasi kerja sering kita dengan atau sangat penting bagi sebuah organisasi atau perusahaan untuk mencapai tujuannya. Dalam konteks pengembangan sumber daya manusia prestasi kerja seorang karyawan dalam sebuah perusahaan sangat dibutuhkan untuk mencapai prestasi kerja bagi karyawan itu sendiri dan juga untuk keberhasilan perusahaan. Prestasi kerja adalah hasil kerja seseorang karyawan selama periode tertentu dibandingkan dengan berbagai kemungkinan misalnya standard, target/sasaran atau kriteria yang telah ditentukan terlebih dahulu dan disepakati bersama.

Menurut Sutrisno (2011:149) prestasi kerja adalah hasil upaya seseorang yang ditentukan oleh kemampuan karakteristik pribadinya serta persepsi terhadap perannya terhadap pekerjaan. Sedangkan menurut Handoko (2012:135) prestasi kerja (performance appraisal) adalah proses melalui mana organisasi-organisasi mengevaluasi dan menilai prestasi kerja karyawan. Dari definisi tersebut dapat dipahami bahwa prestasi kerja lebih menekankan pada hasil atau yang diperoleh dari sebuah pekerjaan sebagai kontribusi pada perusahaan.

Terdapat beberapa penelitian terdahulu yang relevan dengan penelitian ini sehingga bisa dijadikan sebagai dasar penelitian terdahulu. Salah satu penelitian terdahulu adalah penelitian oleh Nur (2013) yang berjudul "Pengaruh Stres Kerja Terhadap Prestasi Kerja Karyawan Pada Perusahaan Pabrik Gula Kebon Agung Malang”. Hipotesis dari penelitian ini adalah adanya pengaruh stres kerja terhadap prestasi kerja karyawan. Untuk menguji hipotesis tersebut diadakan penelitian dengan judul "Pengaruh Stres Kerja Terhadap Prestasi Kerja Karyawan". 
Populasi yang dijadikan sampel dalam penelitian ini adalah sebanyak 60 karyawan. Dalam penelitian ini analisis data yang digunakan adalah model regresi linier berganda. Sebelum melakukan analisis regresi, maka dilakukan uji validitas, reliabilitas, dan uji asumsi klasik, sehingga data yang dihasilkan akan baik. Berdasarkan hasil analisis dapat diketahui stres kerja secara simultan berpengaruh kepada prestasi kerja karyawan dengan signifikansi $0.000>0.05$. Secara parsial signifikansi variabel (X1) Tingkat Lingkungan adalah 0.000, (X2) Tingkat Organisasi 0,037, dan (X3) Tingkat Individu 0.022. Semua variabel dengan signifikansi kurang dari 0.05 sehingga dapat dikatakan Stres Kerja secara simultan dan parsial berpengaruh terhadap Prestasi Kerja Karyawan. Dan variabel bebas yang paling dominan adalah variabel (X3) Tingkat Organisasi dengan signifikansi 0,037.

Penelitian lain adalah penelitian dari Girsang (2010) yang berjudul "Pengaruh Stres Kerja Terhadap Prestasi Kerja Karyawan Pada PT. Cahaya Kawi Ultra Polyntraco Medan". Penelitian ini menggunakan 40 responden dan analisa regresi linier sederhana dan analisa regresi linier sederhana ini menunjukkan bahwa stress kerja mempengaruhi prestasi kerja karyawan pada PT. Cahaya Kawi Ultra Polyntraco Medan yang ditunjukkan dari nilai t hitung $=-4,218$ dengan $p$ value $0,001<{ }^{a}=0,05$. Nilai koefisien determinasi sebesar 0,408 menunjukkan bahwa stress kerja mempunyai pengaruh terhadapif prestasi kerja sebesar $40,80 \%$ dan sisanya sebesar $59,10 \%$ dari prestasi kerja disebabkan oleh variabel lain di luar stress kerja.

Ada juga penelitan dari Kurniawan (2017) yang berjudul "Pengaruh Stres Kerja Terhadap Prestasi Kerja Dengan Mediasi Kecerdasan Emosional, Kecerdasan Moral, dan Kecerdasan Personal Pada Karyawan PT. Sari Warna Textile Industry Unit II Boyolali”. Tujuan dari penelitian ini adalah untuk mengetahui pengaruh stres kerja terhadap prestasi kerja, dengan kecerdasan emosional, kecerdasan moral dan kecerdasan personal sebagai variabel mediasi. Sampel yang diambil sejumlah 200 karyawan di PT. Sari Warna Textile Industry Unit II Boyolali. Teknik pengambilan sampel menggunakan metode purposive sampling. Metode menggunakan kuantitatif, metode analisis data menggunakan Structural Equalition Model (SEM). Dalam memproses data, penelitian ini menggunakan program IBM SPSS Amos versi 21 untuk Windows. Hasil dari penelitian ini menunjukkan bahwa stres kerja berpengaruh negatif dan signifikan terhadap prestasi kerja. Stres kerja berpengaruh signifikan terhadap kecerdasan moral, stres kerja berpengaruh signifikan terhadap kecerdasan personal, tetapi stres kerja tidak berpengaruh signifikan terhadap kecerdasan emosional. Kecerdasan emosional berpengaruh signifikan terhadap prestasi kerja, kecerdasan personal berpengaruh signifikan terhadap prestasi kerja, tetapi kecerdasan moral tidak berpengaruh signifikan terhadap prestasi kerja.

Berdasarkan pada teori dan penelitian-penelitian terdahulu yang telah dikemukakan, dapat dirumuskan hipotesis dari penelitian ini, yaitu:

1. Terdapat tingkat stres kerja dengan prestasi kerja karyawan pada PT. CJ CheilJedang Feed Kalimantan sangat kuat.

2. Terdapat hubungan yang signifikan antara stres kerja dengan prestasi kerja karyawan pada PT. CJ CheilJedang Feed Kalimantan.

\section{Metode Penelitian}

Berpijak pada masalah dan tujuan yang telah dirumuskan, maka dalam penelitian ini digunakan metode Korelasional. Metode Korelasional yakni studi yang membahas tentang derajat hubungan antara variabel-variabel. Ukuran yang dipakai untuk mengetahui derajat hubungan, terutama untuk data kuantitatif, dinamakan koefisien korelasi.

Metode penelitian Analisis Korelasi dipilih karena akan mempelajari hubungan dua variabel atau lebih, yakni hubungan variasi dalam satu variabel dengan variasi dalam variabel 
lain (Zaenal Arifin, 2011:48). Dalam hal ini akan melihat tingkat hubungan stress dengan prestasi kerja terhadap karyawan PT. CJ CheilJedang Feed Kalimantan.

Menurut Sugiyono (2014:80) populasi adalah wilayah generalisasi, obyek/subyek yang mempunyai kualitas dan karakteristik tertentu yang ditetapkan oleh peneliti untuk dipelajari dan kemudian ditarik kesimpulannya. Sedangkan menurut Arikunto (2010:173) populasi adalah keseluruhan dari subjek penelitian. Populasi dalam penelitian ini adalah seluruh karyawan PT. CJ CheilJedang Feed Kalimantan yaitu berjumlah 116 orang.

Dalam penelitian ini penulis menggunakan nonprobability sampling dengan jenis Incidental Sampling.

Menurut Sugiyono (2012:125) Nonprobability Sampling teknik pengambilan sampel yang tidak memberi peluang atau kesempatan sama bagi setiap unsur atau anggota populasi untuk dipilih menjadi sampel. Jenis nonprobability sampling yang digunakan dalam pengambilan sampel pada penelitian ini adalah incidental sampling. Menurut Sugiyono (2012:96) bahwa dikatakan sampling insidental adalah teknik penentuan sampel berdasarkan kebetulan, yaitu siapa saja yang secara kebetulan/insidental bertemu dengan peneliti dapat digunakan sebagai sampel, bila dipandang orang yang kebetulan ditemui itu cocok dengan sumber data.

Untuk menentukan jumlah sampel yang diambil pada penelitian ini menggunakan rumus seperti yang dikemukakan oleh Slovin dengan perhitungan sebagai berikut:

$$
\begin{aligned}
\text { Rumus Slovin }: \mathrm{n} & =\frac{N}{1+N(e)^{2}} \\
& =\frac{\mathbf{1 1 6}}{\mathbf{1 + 1 1 6 ( 0 , 0 5 ) ^ { 2 }}} \\
& =89,92 \text { dibulatkan meenjadi } 90 \text { respinden. }
\end{aligned}
$$

Dimana

$\mathrm{n}$ : jumlah sampel

$\mathrm{N}$ : jumlah populasi

E: persen kelonggaran ketidak-telitian karena kesalahan pengambilan sampel yang masih dapat ditolerir, yaitu 0,05 atau 5\%.

Jadi hasil dari perhitungan menggunakan rumus Slovin untuk mendapatkan sampel yang akan digunakan adalah 90 orang responden dari 116 populasi.

Ada 3 Teknik yang digunakan dalam mengumpulkan data, yaitu:

1. Metode observasi adalah mengadakan pengamatan secara langsung pada kegiatan seharihari karyawan yang dijadikan responden.

2. Wawancara yang mendapatkan informasi dengan cara bertanya langsung kepada responden. Dalam hal ini data diperoleh dengan melakukan wawancara dengan pihak pimpinan, kepala bagian, dan beberapa karyawan untuk mendapatkan informasi yang diinginkan.

3. Kuesioner merupakan metode pengumpulan data melalui penyebaran daftar pertanyaan yang diajukan sehubungan dengan materi penelitian kepada responden yang telah terpilih.

Adapun definisi operasional variabel dalam penelitian ini adalah Stres kerja (X) suatu ketegangan yang menciptakan adanya ketidakseimbangan fisik dan psikis, yang mempengaruhi emosi, proses berpikir, dan kondisi seseorang pegawai (Gaol, 2014:109). Variabel terikat yang diuji adalah Prestasi kerja (Y) yaitu hasil upaya seseorang yang ditentukan oleh kemampuan 
karakteristik pribadinya serta persepsi terhadap perannya terhadap pekerjaan (Sutrisno, 2011:149). Indikator dari variabel stress kerja dan prestasi kerja ditunjukkan pada Tabel 3.

Tabel 3. Indikator Variabel Stres Kerja

\begin{tabular}{ccl}
\hline Variabel & Indikator & \multicolumn{1}{c}{ Butir Pertanyaan } \\
\hline Stres & Beban Kerja & 1. Beban kerja yang berat \\
\cline { 2 - 3 }$(\mathrm{X})$ & & 2. Pekerjaan yang menumpuk \\
\cline { 2 - 3 } & Wewenang dan & 1. Tidak ada wewenang untuk memutuskan \\
\cline { 2 - 3 } & Tanggung Jawab & 2. Tanggung jawab yang tidak sesuai kemampuan \\
\cline { 2 - 3 } & Kondisi Fisik atau & 1. Kesesuaian kondisi fisik pada pekerjaan \\
\cline { 2 - 3 } & Ketidaknyamanan & 2. Kesesuaian kondisi kesehatan pada pekerjaan \\
\cline { 2 - 3 } & Tekanan Kerja & 1. Suasana tempat kerja \\
\cline { 2 - 2 } & 2. Pergaulan di tempat kerja \\
\cline { 2 - 2 } & 2. Tekanan kerja dari pimpinan \\
\hline
\end{tabular}

Sumber:Rivai (2014:724)

Tabel 4. Indikator Variabel Prestasi Kerja

\begin{tabular}{|c|c|c|}
\hline Variabel & Indikator & Butir Pertanyaan \\
\hline \multirow{13}{*}{$\begin{array}{l}\text { Prestasi } \\
\text { Kerja } \\
\text { (Y) }\end{array}$} & Kualitas & 1. Ketepatan \\
\hline & & 2. Ketelitian \\
\hline & & 3. Keterampilan \\
\hline & & 4. Kerapihan kerja \\
\hline & Kuantitas & 1. Banyaknya hasil kerja yang di dapat \\
\hline & & 2. Kecepatan pekerjaan yang dikerjakan \\
\hline & Disiplin & 1. Mengikuti instruksi atasan \\
\hline & & 2. Mematuhi peraturan perusahaan \\
\hline & & 3. Ketaatan waktu kehadiran \\
\hline & Inisiatif & 1. Tidak menunggu perintah saat bekerja \\
\hline & & 2. Mencari solusi baru \\
\hline & Kerjasama & 1. Kemampuan bergaul \\
\hline & & 2. Mampu menyesuaikan diri \\
\hline
\end{tabular}

Sumber:Nasution (2011:99)

Dalam penelitian ini sakala pengukuran yang digunakan adalah skala likert. Untuk analisis data kuantitatif, maka jawaban responden diberi skor dengan pedoman yang ditunjukkan pada Tabel 5.

Tabel 5. Pedoman Penilaian Kuesioner

\begin{tabular}{clc}
\hline No. & \multicolumn{1}{c}{ Sikap Responden } & Skor \\
\hline 1 & Sangat Tidak Setuju & 1 \\
\hline 2 & Tidak Setuju & 2 \\
\hline 3 & Netral & 3 \\
\hline 4 & Setuju & 4 \\
\hline 5 & Sangat Setuju & 5 \\
\hline
\end{tabular}


Kemudian data jawaban tersebut akan menghasilkan data ordinal. Data primer yang berupa skala likert tersebut kemudian dianalisis berdasarkan metode analisis data yang sesuai untuk digunakan pada penelitian ini.

Analisis hasil penelitian dilakukan dengan membuat uji validitas dan reliabilitas instrumen untuk menilai kualitas dari kuesioner yang disebarka. Selanjutnya dilakukan analisis korelasi dengan menggunakan uji koefisien korelasi untuk mengetahui hubungan antara variabel X (Stres Kerja Karyawan) dengan variabel Y (Prestasi Kerja Karyawan). Mencari koefisien korelasi antara variabel X dengan variabel Y dengan menggunakan rumus Korelasi Product Moment sebagai berikut:

$$
\mathrm{r}=\frac{\mathrm{n} \sum \mathrm{XY}-\left(\sum \mathrm{X}\right)\left(\sum \mathrm{Y}\right)}{\sqrt{\left[\mathrm{N} \sum \mathrm{X}^{2}-\left(\sum \mathrm{X}\right)^{2}\left[\mathrm{~N} \sum \mathrm{Y}^{2}-\left(\sum \mathrm{Y}\right)^{2}\right]\right.}}
$$

(Sugiyono, 2012:228)

Keterangan :

r : Koefisien korelasi

X : Variabel X (Stres Kerja Karyawan)

Y : Variabel Y (Prestasi Kerja Karyawan)

n : Banyaknya responden

Untuk dapat memberikan interpretasi seberapa kuat hubungan antara variabel X dan Y, maka dapat digunakan pedoman interpretasi data yang dilihat dalam tabel 6.

Tabel 6. Interpretasi Koefisien Korelasi

\begin{tabular}{cc}
\hline Interval Koefisien & Tingkat Hubungan \\
\hline $0,00-0,199$ & Sangat rendah \\
$0,20-0,399$ & Rendah \\
$0,40-0,599$ & Sedang \\
$0,60-0,799$ & Kuat \\
$0,80-1,000$ & Sangat kuat \\
\hline
\end{tabular}

Sumber : Sugiyono (2014:250)

Berdasarkan hipotesis yang telah dikemukakan, maka bentuk pengujian hipotesis yang akan diuji dalam penelitian ini dapat dirumuskan sebagai berikut:

Ho: Tidak terdapat tingkat stres kerja karyawan dengan prestasi kerja karyawan pada PT. CJ CheilJedang Feed Kalimantan "Kurang Kuat” jika signifikansi < 0,8.

$\mathrm{H}_{\mathrm{I}}$ : Terdapat tingkat stres kerja karyawan dengan prestasi kerja karyawan pada PT. CJ CheilJedang Feed Kalimantan "Sangat Kuat" jika signifikansi > 0,8.

Ho: Tidak terdapat hubungan yang signifikan antara stres kerja karyawan dengan prestasi karyawan pada PT. CJ CheilJedang Feed Kalimantan.

$\mathrm{H}_{\mathrm{I}}$ : Terdapat hubungan yang signifikan antara stres kerja karyawan dengan prestasi kerja karyawan pada PT. CJ CheilJedang Feed Kalimantan. 


\section{Hasil Penelitian dan Pembahasan}

Data yang dikumpulkan dalam penelitian ini dilakukan melalui penyebaran kuesioner kepada karyawan PT. CJ CheilJedang Feed Kalimantan yang menjadi responden. Jumlah kuesioner yang dibagikan sebanyak 90 (sembilan puluh) kuesioner, namun hasil dari penyebaran kuesioner yang didapat hanya 68 (enam puluh delapan ) responden. Karena ada bermacam faktor atau alasan kenapa kuesioner yang disebarkan tidak 90 (sembilan puluh) responden. Alasannya karena setelah 3 (tiga) hari tenggang waktu yang diberikan kepada reponden untuk mengisi, namun ketika diambil kembali kuesioner hilang atau sudah tidak ada, kuesioner yang di isi juga tidak layak untuk dianalisis karena mengisi dengan cara asal - asalan.

Analisis deskriptif digunakan untuk menganalisis data dengan cara mendeskripsikan atau menggambarkan data yang telah terkumpul sebagaimana adanya tanpa bermaksud membuat kesimpulan yang berlaku untuk umum atau generalisasi (Sugiyono, 2013: 147), adapaun jawaban responden untuk jawaban pertanyaan variabel Stres Kerja (X) dan Prestasi Kerja (Y) dapat dilihat pada tabel 7 dan 8 .

Tabel 7. Distribusi Frekuensi Item Variabel Stres Kerja $(\mathbf{X})$

\begin{tabular}{ccccccccccc}
\hline \multicolumn{10}{c}{} & \multicolumn{10}{c}{ Jawaban Responden } \\
\hline Item & \multicolumn{2}{c}{ STS } & \multicolumn{2}{c}{ TS } & \multicolumn{1}{c}{ N } & \multicolumn{2}{c}{ S } & \multicolumn{2}{c}{ SS } \\
\hline & F & \% & F & \% & f & \% & f & \% & f & \% \\
\hline $\mathrm{X} 1.1$ & - & - & 47 & $67 \%$ & 20 & $28,6 \%$ & 1 & $1,4 \%$ & - & - \\
\hline $\mathrm{X} 1.2$ & 1 & $1,4 \%$ & 23 & $32,9 \%$ & 25 & $35,7 \%$ & 19 & $27,1 \%$ & - & - \\
\hline $\mathrm{X} 2.1$ & 4 & $5,7 \%$ & 51 & $72,9 \%$ & 13 & $18,6 \%$ & - & - & - & - \\
\hline $\mathrm{X} 2.2$ & 2 & $2,9 \%$ & 45 & $64,3 \%$ & 16 & $22,9 \%$ & 5 & $7,1 \%$ & - & - \\
\hline $\mathrm{X} 3.1$ & 2 & $2,9 \%$ & 52 & $74,3 \%$ & 12 & $17,1 \%$ & 2 & $2,9 \%$ & - & - \\
\hline $\mathrm{X} 3.2$ & 5 & $7,1 \%$ & 50 & $71,4 \%$ & 12 & $17,1 \%$ & 1 & $1,4 \%$ & - & - \\
\hline $\mathrm{X} 4.1$ & - & - & 19 & $27,1 \%$ & 44 & $62,9 \%$ & 5 & $7,1 \%$ & - & - \\
\hline $\mathrm{X} 4.2$ & 14 & $20,0 \%$ & 48 & $68,6 \%$ & 3 & $4,3 \%$ & 3 & $4,3 \%$ & - & - \\
\hline $\mathrm{X} 5.1$ & 31 & $44,3 \%$ & 27 & $38,6 \%$ & 9 & $12,9 \%$ & 1 & 1,4 & - & - \\
\hline $\mathrm{X} 5.2$ & 11 & $15,7 \%$ & 51 & $72,9 \%$ & 6 & $8,6 \%$ & - & - & - & - \\
\hline
\end{tabular}

Tabel 8. Distribusi Frekuensi Item Variabel Prestasi Kerja (Y)

\begin{tabular}{|c|c|c|c|c|c|c|c|c|c|c|}
\hline \multicolumn{11}{|c|}{ Jawaban Responden } \\
\hline \multirow[t]{2}{*}{ Item } & \multicolumn{2}{|c|}{ STS } & \multicolumn{2}{|c|}{ TS } & \multicolumn{2}{|c|}{$\mathrm{N}$} & \multicolumn{2}{|c|}{$\mathrm{S}$} & \multicolumn{2}{|c|}{ SS } \\
\hline & $\mathrm{f}$ & $\%$ & $\mathrm{f}$ & $\%$ & $\mathrm{~F}$ & $\%$ & $\mathrm{f}$ & $\%$ & $\mathrm{~F}$ & $\%$ \\
\hline Y1.1 & 1 & $1,4 \%$ & 1 & $1,4 \%$ & 14 & $20,0 \%$ & 48 & $68,6 \%$ & 4 & $5,7 \%$ \\
\hline $\mathrm{Y} 1.2$ & - & - & - & - & 23 & $32,9 \%$ & 43 & $61,4 \%$ & 2 & $2,9 \%$ \\
\hline $\mathrm{Y} 1.3$ & - & - & - & - & 40 & $57,1 \%$ & 27 & $38,6 \%$ & 1 & $1,4 \%$ \\
\hline $\mathrm{Y} 1.4$ & - & - & - & - & 32 & $45,7 \%$ & 27 & $38,6 \%$ & 1 & $1,4 \%$ \\
\hline Y2.1 & - & - & 1 & $1,4 \%$ & 4 & $5,7 \%$ & 60 & $85,7 \%$ & 3 & $4,3 \%$ \\
\hline Y2.2 & - & - & - & - & 49 & $70,0 \%$ & 18 & $25,7 \%$ & 1 & $1,4 \%$ \\
\hline Y3.1 & - & - & - & - & 8 & $11,4 \%$ & 54 & $77,1 \%$ & 6 & $8,6 \%$ \\
\hline Y3.2 & - & - & - & - & 14 & $20,0 \%$ & 47 & $67,1 \%$ & 7 & $10,0 \%$ \\
\hline Y3.3 & - & - & - & - & 15 & $21,4 \%$ & 51 & $72,9 \%$ & 2 & $2,9 \%$ \\
\hline Y4.1 & - & - & - & - & 6 & $8,6 \%$ & 59 & $84,3 \%$ & 2 & $2,9 \%$ \\
\hline Y4.2 & - & - & 1 & $1,4 \%$ & 48 & $68,6 \%$ & 17 & $24,3 \%$ & 2 & $2,9 \%$ \\
\hline Y5.1 & - & - & - & - & 2 & $2,9 \%$ & 59 & $84,3 \%$ & 7 & $10,0 \%$ \\
\hline Y5.2 & - & - & - & - & 3 & $4,3 \%$ & 59 & $84,3 \%$ & 6 & $8,6 \%$ \\
\hline
\end{tabular}


Dapat dilihat dalam tabel 7 frekuensi untuk variabel stres kerja, adalah yang paling sedikit responden menjawab "Tidak Setuju" pada item X4.1 dimana karyawan merasa bahwa suasana ditempat kerja tidak jauh berbeda dengan kehidupan sehari - hari. Selain itu, terdapat pada item X5.1 yang mana responden juga mengatakan "Tidak Setuju" dengan persen sedikit pada pernyataan tersebut. Karena responden merasa pimpinan di perusahaan selalu meminta untuk mengerjakan tugas dengan kemampuan dari karyawan itu sendiri. Pada tabel 8 untuk frekuensi item variabel prestasi kerja, responden rata - rata menjawab setuju untuk pernyataan yang terdapat dalam kuesioner. Dan dapat dilihat pada item Y2.1 dengan jumlah persen yang paling tinggi, yang artinya prestasi kerja karyawan pada PT. CJ CheilJedang Feed Kalimantan dapat dilihat dan diukur dari penyelesaian tugas yang diberikan dari atasan atau pimpinan dengan tenggang waktu yang sudah ditentukan.

Pengujian validitas dilakukan dengan metode korelasi yaitu dengan melihat angka koefisien korelasi (rxy) dan nilai signifikansinya pada item korelasi yang menyatakan hubungan antara skor pertanyaan dengan skor total. Dengan jumlah sampel uji coba kuesioner sebanyak 90 (Sembilan puluh) responden sebanyak 10 (dua puluh tiga) pernyataan untuk variabel Stres Kerja (X) dan sebanyak 13 (tiga belas) pernyataan untuk variabel Prestasi Kerja (Y), maka dilakukan analisis korelasi antara skor pernyataan dengan skor total.

Apabila nilai signifikansinya $<$ level of significant $5 \%=0,05$ dan nilai koefisien korelasi (rxy) $>0,30$, maka dapat dinyatakan item tersebut valid, sehingga seluruh pernyataan dalam kuesioner dinyatakan valid. Selanjutnya kuesioner tersebut akan digunakan dalam penelitian.

Pengujian reliabilitas dilakukan dengan teknik cronbach alpha, dengan jumlah sampel uji coba kuesioner sebanyak 90 (sembilan puluh) responden. Suatu instrument penelitian dinyatakan reliabel apabila nilai $r$ alpha $>0,60$. Perhitungan reliabilitas alat ukur penelitian ini dilakukan dengan bantuan program IBM SPSS Statistics 24, seperti ditunjukkan pada Tabel 9.

Tabel 9. Hasil Uji Validitas dan Reliabilitas

\begin{tabular}{|c|c|c|c|c|c|c|c|}
\hline Var & Item & $\mathrm{R}$ & $r_{\text {syarat }}$ & Ket & $\alpha$ & Syarat & Ket \\
\hline Stres & $\mathrm{X} 1.1$ & 0,568 & 0,3 & Valid & 0,654 & 0,60 & Reliabel \\
\hline \multirow[t]{9}{*}{ Kerja (X) } & $\mathrm{X} 1.2$ & 0,430 & 0,3 & Valid & & & \\
\hline & $\mathrm{X} 2.1$ & 0,328 & 0,3 & Valid & & & \\
\hline & $\mathrm{X} 2.2$ & 0,438 & 0,3 & Valid & & & \\
\hline & X3.1 & 0,603 & 0,3 & Valid & & & \\
\hline & X3.2 & 0,530 & 0,3 & Valid & & & \\
\hline & X 4.1 & 0,291 & 0,3 & Tidak Valid & & & \\
\hline & $\mathrm{X} 4.2$ & 0,486 & 0,3 & Valid & & & \\
\hline & X5.1 & 0,726 & 0,3 & Valid & & & \\
\hline & X5.2 & 0,578 & 0,3 & Valid & & & \\
\hline Prestasi & Y1.1 & 0,563 & 0,3 & Valid & 0,201 & 0,60 & Tidak \\
\hline \multirow[t]{12}{*}{ Kerja (Y) } & $\mathrm{Y} 1.2$ & 0,461 & 0,3 & Valid & & & \\
\hline & Y1.3 & 0,599 & 0,3 & Valid & & & Reliabel \\
\hline & Y1.4 & 0,490 & 0,3 & Valid & & & \\
\hline & Y2.1 & 0,433 & 0,3 & Valid & & & \\
\hline & Y2.2 & 0,459 & 0,3 & Valid & & & \\
\hline & Y3.1 & 0,350 & 0,3 & Valid & & & \\
\hline & Y3.2 & 0,472 & 0,3 & Valid & & & \\
\hline & Y3.3 & 0,480 & 0,3 & Valid & & & \\
\hline & Y4.1 & 0,025 & 0,3 & Tidak Valid & & & \\
\hline & Y4.2 & 0,534 & 0,3 & Valid & & & \\
\hline & Y5.1 & 0,432 & 0,3 & Valid & & & \\
\hline & Y5.2 & 0,250 & 0,3 & Tidak Valid & & & \\
\hline
\end{tabular}


Dari hasil diatas masih terdapat item - item indikator variabel stres kerja dengan prestasi kerja yang "Tidak Valid" dan "Tidak Reliabel" yang artinya dapat dikatakan bahwa item - item indikator variabel yang tidak valid dan tidak reliabel tidak bisa dipakai untuk pengukur dari variabel stres kerja dengan prestasi kerja.

Maka dari itu dilakukan pengujian ulang dengan menghilangkan item - item indikator variabel yang tidak valid dan tidak reliabel, sehingga jumlah indikatornya menjadi berkurang dan dilakukan uji ulang seperti ditunjukkan pada Tabel 10.

Tabel 10. Hasil Uji Validitas dan Reliabilitas Tanpa Hasil Yang "Tidak Valid"

\begin{tabular}{|c|c|c|c|c|c|c|c|}
\hline Var & Item & $\mathrm{R}$ & $r_{\text {syarat }}$ & Ket & $\alpha$ & Syarat & Ket \\
\hline \multirow{9}{*}{$\begin{array}{l}\text { Stres Kerja } \\
\text { (X) }\end{array}$} & X1.1 & 0,557 & 0,3 & Valid & \multirow[t]{9}{*}{0,668} & \multirow[t]{9}{*}{0,60} & \multirow[t]{9}{*}{ Reliabel } \\
\hline & $\mathrm{X} 1.2$ & 0,466 & 0,3 & Valid & & & \\
\hline & X2.1 & 0,332 & 0,3 & Valid & & & \\
\hline & $\mathrm{X} 2.2$ & 0,496 & 0,3 & Valid & & & \\
\hline & X3.1 & 0,647 & 0,3 & Valid & & & \\
\hline & X3.2 & 0,571 & 0,3 & Valid & & & \\
\hline & $\mathrm{X} 4.2$ & 0,448 & 0,3 & Valid & & & \\
\hline & X5.1 & 0,704 & 0,3 & Valid & & & \\
\hline & X5.2 & 0,547 & 0,3 & Valid & & & \\
\hline Prestasi & Y1.1 & 0,588 & 0,3 & Valid & \multirow[t]{11}{*}{0,707} & \multirow[t]{11}{*}{0,60} & \multirow[t]{11}{*}{ Reliabel } \\
\hline \multirow[t]{10}{*}{ Kerja (Y) } & Y1.2 & 0,470 & 0,3 & Valid & & & \\
\hline & Y1.3 & 0,642 & 0,3 & Valid & & & \\
\hline & Y1.4 & 0,539 & 0,3 & Valid & & & \\
\hline & Y2.1 & 0,505 & 0,3 & Valid & & & \\
\hline & Y 2.2 & 0,502 & 0,3 & Valid & & & \\
\hline & Y3.1 & 0,425 & 0,3 & Valid & & & \\
\hline & Y3.2 & 0,543 & 0,3 & Valid & & & \\
\hline & Y3.3 & 0,452 & 0,3 & Valid & & & \\
\hline & Y4.2 & 0,508 & 0,3 & Valid & & & \\
\hline & Y5.1 & 0,346 & 0,3 & Valid & & & \\
\hline
\end{tabular}

Setelah dilakukan pengujian ulang dengan menghilangkan atau membuang hasil yang tidak valid dan tidak reliabel, maka semua indikator variabel stres kerja dengan prestasi kerja karyawan pada PT. CJ CheilJedang Feed Kalimantan menjadi "Valid" dan "Reliabel".

Hasil analisis korelasi hubungan antara variabel Stres Kerja (X) dengan Prestasi Kerja (Y) karyawan pada PT. CJ CheilJedang Feed Kalimantan dapat dilihat pada tabel 11.

Tabel 11. Analisis Korelasi Hubungan Stres Kerja (X) dengan Prestasi Kerja (Y) Karyawan Pada PT. CJ CheilJedang Feed Kalimantan

\begin{tabular}{ccc}
\hline Variabel & Signifikansi & Syarat \\
\hline Stres Kerja $(\mathrm{X})$ Dan Prestasi Kerja $(\mathrm{Y})$ & 0,809 & $<0,05$ \\
\hline
\end{tabular}

Berdasarkan hasil analisis korelasi pada tabel 11 maka dapat disimpulkan bahwa antara variabel Stres Kerja (X) dengan Prestasi Kerja (Y) nilai yang didapat tidak dapat dikatakan signifikan karena hasil yang didapat tidak sesuai dengan syarat. Nilai yang seharusnya didapat $<0,05$ sedangkan hasil analisis korelasinya melebihi pada 0,05 .

Dari hasil korelasi tersebut dapat diartikan tidak terdapat hubungan yang signifikan antara variabel Stres Kerja dengan Prestasi Kerja, dan dapat disimpulkan bahwa tingkat Stres Kerja yang dialami karyawan pada PT. CJ CheilJedang Feed Kalimantan tidak sama sekali mempengaruhi pada Prestasi Kerja karyawan.

Tingkat stres kerja dengan prestasi kerja karyawan pada PT. CJ CheilJedang Feed Kalimantan pada penelitian ini ketika karyawan mengalami stres kerja, itu tidak akan 
mempengaruhi pada prestasi kerjanya. Karena tingkat stres kerja dengan prestasi kerja pada penelitian ini terbilang rendah namun tidak juga sangat rendah.

Stres kerja yang dialami karyawan pada PT. CJ CheilJedang Feed Kalimantan ketika mengalami stres yang tinggi atau rendah itu tidak akan mempengaruhi pada prestasi kerja karyawan. Karena setelah dilakukan wawancara, banyak berbagai alasan dan sebab mengapa karyawan pada PT. CJ CheilJedang Feed Kalimantan tidak sama sekali prestasi kerjanya terpengaruh oleh stres yang dialami.

Alasan atau sebab dari karyawan pada PT. CJ CheilJedang Feed Kalimantan karena suasana dan tempat kerja yang tidak jauh berbeda dengan suasana dirumah. Karena hal utama yang diinginkan karyawan saat bekerja adalah suasana dan tempat yang nyaman. Selain itu juga, alasan mengapa karyawan tidak terganggu dalam prestasi kerjanya walaupun sedang mengalami stres kerja adalah dengan adanya sarana yang terdapat di perusahaan. Sarana yang terdapat di perusahaan tergolong lengkap sehingga memudahkan karyawan untuk melakukan segala sesuatunya. Misalnya, ketika karyawan ingin menemui customer hanya dengan menghubungi driver yang memang sudah disediakan dari perusahaan. Juga di perusahaan dilengkapi dengan teknologi yang memadai.

Alasan yang lain sehingga menjadikan faktor mengapa karyawan tetap berprestasi adalah setiap bulan selalu mengadakan hang out atau santai bersama diluar dari pokok pembahasan sehari-hari yaitu bekerja dengan pergi ke suatu tempat contohnya pergi ke Cafe, tempat karaoke, pantai dan tempat wisata lainnya. Karena kebijakan dari perusahaan sendiri agar karyawan merasa nyaman dan bertahan bekerja bertahun - tahun diperusahaan adalah dengan cara mencari hiburan lain selain fokus dalam hal pekerjaan.

Selain itu juga adalah dengan adanya pimpinan dan manajer yang sangat bisa menjadi panutan untuk para karyawan. Pimpinan ketika memberikan tugas sesuai dengan kemampuan karyawannya dan tidak membatasi ruang gerak terhadap karyawan. Dan masih banyak lagi alasan - alasan mengapa karyawan pada PT. CJ CheilJedang Feed Kalimantan walaupun mengalami stres dalam bekerja namun tetap mempertahankan prestasi kerjanya.

Hubungan antara variabel stres kerja dengan prestasi kerja ternyata mendapatkan hasil bahwa tingkat stres kerja karyawan pada PT. CJ CheilJedang Feed Kalimantan dapat dikatakan rendah namun tidak sangat rendah. Dan hasil dari uji korelasi menunjukkan hubungan antara variabel stres kerja dengan prestasi kerja karyawan adalah tidak signifikan. Rendahnya stres kerja yang terjadi pada PT. CJ CheilJedang Feed Kalimantan karena banyak faktor yang menjadi alasan. Salah satu alasan mengapa stres kerja karyawan pada PT. CJ CheilJedang Feed Kalimantan rendah karena di perusahaan banyak sekali fasilitas dan keuntungan sehingga dapat memudahkan karyawan untuk melakukan segala hal aktifitas dikantor.

Sehingga alasan tersebut menjadi faktor mengapa prestasi kerja karyawan pada PT. CJ CheilJedang Feed Kalimantan tetap tergolong tinggi atau bertahan pada posisi aman. Dan karena itu hubungan antara variabel stres kerja dengan prestasi kerja tidak signifkan atau tidak berhubungan erat.

\section{Kesimpulan}

Berdasarkan hasil penelitian pada BAB IV, maka dapat ditarik beberapa kesimpulan sebagai berikut:

1. Tingkat stres kerja dengan prestasi kerja karyawan pada PT. CJ CheilJedang Feed Kalimantan tergolong dikatakan rendah namun tidak sangat rendah. Mengapa dikatakan rendah karena ketika karyawan mengalami stres dalam bekerja tetapi itu tidak akan mempengaruhi pada prestasi kerjanya.

2. Hubungan antara stres kerja dengan prestasi kerja karyawan pada PT. CJ Cheiljedang Feed Kalimantan mendapatkan hasil yang tidak signifikan. Karena nilai yang dihasilkan dari 
hubungan atau korelasi antara variabel stres kerja dengan prestasi kerja ternyata tidak memenuhi standar. Sehingga dapat disimpulkan bahwa tidak ada hubungan yang erat antara variabel Stres Kerja dengan Prestasi Kerja karyawan

\section{DAFTAR PUSTAKA}

Arikunto, Suharsimi, 2010, Prosedur Penelitian, PT. Rineka Cipta, Jakarta

Gaol, Chr. J. L, 2014, A to Z Human Capital. PT. Gramedia Widiasarana Indonesia, Jakarta

Girsang, Erlinawati, 2010, Pengaruh Stres Kerja Terhadap Prestasi Kerja Karyawan Bagian Produksi Pada PT. Cahaya Kawi Ultra Polyntraco Medan, Skripsi Dipublikasikan, Jurusan Manajemen Universitas Sumatera Utara, Medan

Handoko, T. Hani, 2012, Manajemen Personalia dan Sumber Daya Manusia, Cetakan Kesembilan Belas, Penerbit BPFE, Yogyakarta

Hermita, 2011, Pengaruh Stres Kerja Terhadap Karyawan Pada PT. Semen Tonasa (Persero), Universitas Hasanuddin, Makassar

Nasution, 2011, Metode Research, Bumi Aksara, Jakarta

Sugiyono, 2012, Metodologi Penelitian Kuantitatif Kualitatif dan R\&D, Alfabeta, Bandung

Sutrisno, Edy, 2011, Manajemen Sumber Daya Manusia, Cetakan Ketiga, Kencana Prenada Media Group, Jakarta

Thoha, Miftah, 2014, Perilaku Organisasi, Konsep Dasar dan Aplikasinya, Cetakan Kesembilan Belas, Rajawali Pers, Yogyakarta

Waluyo, M., 2014, Perpajakan Indonesia, Salemba Empat, Jakarta 